\title{
Notas sobre formação, forma e processo social em Ismail Xavier
}

\author{
Notes on formation, form and social process \\ in Ismail Xavier
}

Rafael Marino*

\section{RESUMO}

O presente trabalho tentará entender a experiência intelectual de Ismail Xavier a partir de dois prismas distintos, porém, em certo sentido, complementares: os ensaios sobre a formação do Brasil e os estudos a respeito da constituição de uma forma artística que desse conta de nossas especificidades socio-históricas. Para tal, lançaremos mão dos seguintes passos: i) uma breve introdução sobre a questão da formação; ii) uma exposição de alguns lineamentos do pensamento de Ismail Xavier, notadamente seus estudos a respeito do cinema de Glauber Rocha e iii) uma retomada do que fora exposto.

Palavras-chave: pensamento político e social brasileiro, formação, Ismail Xavier.

\begin{abstract}
The present work will try to understand the intellectual experience of Ismail Xavier based on two distinct prisms, however, in a certain sense, complementary: the essays on the formation of Brazil and the studies on the constitution of an artistic form that would give account of our socio-historical specificities. To this end, we will use the following steps: i) a brief introduction on the issue about formation; ii) an exhibition of some lines of thought by Ismail Xavier, notably his studies on Glauber Rocha's cinema and iii) a resumption of what was exposed.
\end{abstract}

Keywords: Brazilian political and social thought, formation, Ismail Xavier.

\footnotetext{
* Universidade de São Paulo, São Paulo, SP, Brasil.

Doutorando e mestre em Ciência Política (USP).rafael.marino@usp.br
} 


\section{Introdução}

O presente artigo tem a intenção de expor como a experiência intelectual de Ismail Xavier contou com duas determinações essenciais, as quais, em boa medida, andam juntas: os ensaios e a discussão sobre a formação no pensamento político e social brasileiro e as teorizações sobre a relação entre formação e a constituição de uma forma artística travejada por essa formação social e histórica - que é diversa, mas não alheia ao concerto das nações no mundo. De forma subsidiária, tendo em vista essa exposição a respeito da experiência intelectual de Xavier, pretende-se argumentar que a categoria de formação - e as discussões que enseja a respeito de formas artísticas no Brasil - ainda são decisivas para se pensar a produção e circulação de artefatos simbólicos (ideias, literatura, artes visuais, cinema etc.) e de sistemas artísticos e simbólicos no Brasil.

Para dar consecução a esses objetivos, lançaremos mão das seguintes etapas expositivas: (i) exposições sobre a categoria de formação, sobre a discussão que nela pode ser feita a respeito da forma artística e a apresentação dos argumentos de críticos dessa perspectiva; (ii) uma exposição a respeito da experiência intelectual de Ismail Xavier, enfatizando seus ensaios a respeito de Glauber Rocha, desde os quais se pode capturar, em maior densidade e desenvolvimento, as discussões que faz sobre forma e formação e (iii) uma breve discussão a respeito do que foi exposto por nós.

O primeiro movimento do texto tem a função de inserir nossa leitura de Ismail Xavier num contexto mais amplo a respeito das discussões sobre a categoria de formação e algumas de suas consequências. O segundo momento propicia uma abordagem direta do assunto que queremos tratar, cujo recorte se justifica pelo fato de, em linhas gerais, o cinema de Glauber Rocha ser uma espécie de ponto focal desde o qual Xavier pode deslindar a constituição de uma forma que abarque as condições sociohistóricas formativas do Brasil e, nesse sentido, analisar a constituição de um sistema cinematográfico maduro no país. Aproxima-o, assim, das reflexões - abaixo expostas - de Antonio Candido a respeito de um sistema literário no Brasil. A terceira parte pretende retomar e rediscutir o que foi trabalhado ao longo do texto. 


\section{Formação, forma e seus críticos: lineamentos}

De acordo com Otília Arantes e Paulo Arantes (1997), a quantidade de livros que tinham em seu título a categoria formação dava conta da obsessão de parcela significativa do pensamento político brasileiro a respeito da temática. Essa formulação indicaria a centralidade de um ideal formativo no pensamento político e social brasileiro, baseado em um referencial europeu, de nações integradas. De sorte que a categoria de formação era uma referência quase que comum à intelectualidade brasileira, até porque, segundo Paulo Arantes, "desde os primórdios da nacionalidade [...], a nossa vida mental sempre girou em torno do esforço, a um tempo de ilustração e expressão, voltado para a desobstrução das vias de passagem da Colônia para a Nação" (Arantes, 1996, p. 93).

Não seria possível dar conta de todos os ensaios listados pelos autores ou mesmo da maior parte deles. Portanto nos deteremos naqueles que julgamos ser mais ilustrativos do sentido formativo e do ideal de integração destacados anteriormente, no caso: Caio Prado Júnior, Formação do Brasil contemporâneo: colônia, e Celso Furtado, Formação econômica do Brasil. Utilizaremos ainda o livro de Antonio Candido, Formação da literatura brasileira, como um caso, em certa medida, diferencial, e, nesse sentido, revelador. Por um lado, como argumenta Schwarz, em Prado Jr. e Furtado “o ponto de fuga [...] é fortemente impregnado de valor, positivo ou negativo, e diz respeito direto à atualidade vivida pelos autores" (Schwarz, 2014, p. 19). Já Candido corresponde a um ponto de vista diferenciado, até porque o sistema literário é entendido pelo autor como um fato, com suas vantagens e dificuldades a serem especificadas; desse modo, as ilusões redentoras do nacionalismo não estão explicitamente presentes (Candido, 2011, p. 169197). Não por acaso, a categoria formação, em Candido, é utilizada de modo sóbrio e sua normatividade é descrita apenas de fora. Sinal disso é que, de acordo com Schwarz, formado, o sistema literário convivia com a escravidão e as "anomalias" coloniais (Schwarz, 2014).

Além disso, é possível argumentar que haveria uma familiaridade no tratamento da questão formativa em Prado Jr. e Furtado, na medida em que atribuem "grande importância a fatores externos na determinação dos destinos do Brasil” (Ricupero, 2011, p. 149). Há também uma relação 
interna entres os textos de Prado Jr., Furtado e Candido, que os diferencia dos demais livros de que falavam Arantes e Arantes (1997). Ou seja, ensaios como Os donos do poder, de Faoro, Casa-grande e senzala, de Freyre e Raízes do Brasil, de Holanda, apesar de terem a formação em seus subtítulos ou no espírito do texto, não têm como preocupação central a passagem da colônia para nação (Ricupero, 2010, p. 4). No caso de Faoro e Freyre, operase, respectivamente, com uma crítica democrática a um patronato político formado em Portugal e para cá exportado e com uma visão passadista da família patriarcal já formada.

Numa outra referência, pretendemos argumentar em favor da atualidade da categoria de formação. Defendemos que a temática formativa é mesmo um problema objetivo da sociedade brasileira, que ganhou uma formalização teórica em alguns autores. Em outras palavras, a categoria de formação seria essencial para se pensar e esquadrinhar produções simbólicas variadas feitas no Brasil, como ideias, arte visuais, filmes, literatura etc. Nesse mesmo sentido, poder-se-ia notar em meio a esses escritos um sentido crítico mais profundo. Dessa maneira, por meio da redução estrutural de nossa sociedade, na forma artística e nos ensaios de intepretação, poder-se-ia vislumbrar uma crítica ao que era tomado como pressuposto formal do centro capitalista.

Caio Prado Jr. (2011) toma a colonização brasileira como um produto da expansão ultramarina portuguesa, de modo que caracteriza a colonização do Brasil como uma colonização de exploração, a qual teria ocorrido principalmente nas zonas tropical e semitropical das Américas. Sendo assim, seria pautada, essencialmente, em interesses comerciais pela produção de gêneros de grande valor comercial e não, como nas colônias de povoamento, em uma "ética" do trabalho, ou mesmo na constituição de uma sociedade (Nova Inglaterra, por exemplo). No entanto, paradoxalmente, Caio Prado Júnior aponta que nas colônias de exploração surgiram sociedades, por assim dizer, originais, enquanto aquelas de povoamento constituem-se quase como um prolongamento da Europa.

Essa grande exploração colonial teria uma importância decisiva na estrutura social, na organização política e na própria cultura. A escravidão seria o traço mais marcante da sociedade, influenciando todos os demais setores da vida social, desde a organização econômica até os padrões morais e materiais, com nada passando incólume por ela. Escravidão ressurgida das cinzas da Antiguidade e que volta, a partir das exigências impostas 
pela expansão comercial europeia. Ademais, Prado Jr. (2011, p. 378) chama a atenção para o chamado setor inorgânico, caótico e, muitas vezes, caracterizado de maneira negativa pelo autor: "incoerência e instabilidade no povoamento; pobreza e miséria na economia; dissolução dos costumes; inércia e corrupção nos dirigentes leigos e eclesiásticos”. Dele fariam parte a produção voltada para o consumo interno, a exemplo da pecuária e outras atividades de difícil tipificação. Um setor cuja participação na estrutura social brasileira veio se incrementando ao longo do tempo, apontado pelo autor, ironicamente, como o principal fator para a constituição da sociedade, pois o que seria prejudicial para a grande exploração - no caso a produção voltada para o consumo interno - transforma-se em uma condição essencial para formar a nação. Portanto, Caio Prado Jr. aponta a necessidade de superação de uma condição que não integrara a maior parte da população. Isto é, haveria a superação do "sentido da colonização" por meio da generalização da mão de obra livre, da industrialização brasileira e da formação de um mercado interno. Esses seriam pontos fulcrais para a constituição de uma nação como uma sociedade autossuficiente do ponto de vista econômico.

Em poucas palavras, Caio Prado Jr. (2011), em meio aos diversos sentidos do termo formação, fala na possibilidade (ou virtualidade) da formação de uma nação integrada, a qual não se realizou - ao menos ainda. Integração que deve ser entendida como negação do corpo social organizado de modo a saciar as demandas de fora do país, de sorte que este passaria a ser configurado no intuito de suprir as necessidades da coletividade nacional, desbancando a herança colonial de inorganicidade social (Schwarz, 2014).

Em relação a Celso Furtado, percebem-se algumas inquietações que nos lembram as preocupações de Prado Jr. Em seu livro Formação econômica do Brasil (Furtado, 1995), argumenta que, na primeira metade do século 20, há a emergência de um novo sistema no Brasil, cujo principal centro dinâmico é o mercado interno. Em contraste, num primeiro momento do desenvolvimento das regiões de pouca povoação e de natureza abundante, observa-se uma expansão do setor externo que possibilita uma alta capitalização e permite a incorporação de progresso técnico. Num segundo momento, marcado pelos inícios da Primeira Guerra mundial e as dificuldades de importação de manufaturas e produtos decorrente destas, diminui-se o papel do comércio exterior como fator no nível de renda, mas, por outro lado, há o aumento de sua importância como elemento no processo de formação de capital. 
O economista, julga, a partir daí, que o desenvolvimento no Brasil nos primeiros cinquenta anos do século 20 dá-se sob o signo da articulação das distintas regiões em um sistema com um mínimo de integração - com um forte desenvolvimento de algumas regiões e não de outras. Um dos principais problemas na política econômica para os anos decorrentes, consequentemente, segundo Furtado, seria pensar uma integração de outra ordem, muita mais profunda. Tal integração, em suma, "teria de orientar-se no sentido do aproveitamento mais racional de recursos e fatores no conjunto da economia nacional” (Furtado, 1995, p. 240). Isso estaria pautado num projeto modernizador, de ruptura com o arcaico e aproveitamento racional dos recursos, sob a orientação de um planejamento nacional.

Em suma, de modo semelhante a Caio Prado Jr., a formação de que fala Furtado também ficaria para o futuro. Ou seja, a formação de um mercado interno que contemple o conjunto da população brasileira e que seja o eixo fundamental de desenvolvimento do país é basicamente um projeto. Em outras palavras, tanto para Prado Jr. quanto para Furtado, a formação tratarse-ia de uma virtualidade. Nesse sentido, ambos acreditavam que depois de o mercado interno e a nação alcançarem a completude formativa, ocorreria a ruptura com o passado e o Brasil finalmente se transformaria em um país internamente integrado.

Já Candido terá uma visão mais sóbria e realista do processo, até porque tratará da formação da literatura brasileira, a qual, nas desventuras da dialética entre localismo e cosmopolitismo, formou-se. O crítico literário tinha como objetivo reconstruir a história dos brasileiros no seu desejo de ter uma literatura, tendo em vista um processo difícil de autonomização entre os séculos 18 e 19. É preciso dizer que o crítico identifica dois momentos decisivos para essa formação: Arcadismo - essencialmente universalista e convencional - e o Romantismo - assentado na especificidade e na individualização. Na sua análise, Candido aproveita-se do trabalho de seus predecessores, como Silvio Romero e José Veríssimo. Consegue perceber, a partir daí, um movimento de continuidade em momentos díspares de uma literatura empenhada, preocupada com a "independência nacional" e a "tarefa de criar um país que participasse da cultura comum do Ocidente e que guardasse fisionomia própria” (Schwarz, 2014, p. 59).

Candido argumenta que, para compreender o sentido da categoria formação por ele utilizada, era preciso ter em mente a distinção entre manifestações 
literárias e a literatura propriamente dita, esta entendida como um sistema de obras conectadas por características comuns. Características que podem ser de natureza interna, social ou psíquica, organizadas pela literatura e que se apresentam historicamente, das quais as mais importantes são: um conjunto de produtores literários; um conjunto de receptores, formadores de públicos distintos, e um conjunto de obras, ou uma linguagem traduzida em estilos, que liga uns aos outros. A partir daí, ter-se-ia um sistema simbólico de comunicação humana conhecido como literatura (Candido, 2013). Esse enquadramento permite que se encare a história literária de acordo com um problema - e não mais a partir de uma linearidade temporal -, tendo em vista os momentos decisivos citados. Forja-se, assim, uma nova periodização, a partir de um critério interno à literatura em movimento.

É preciso indicar ainda que, com a divisão entre manifestação e literatura, Candido dava forma à própria experiência intelectual brasileira. A literatura é um fato cultural que não surge acabado, mas sim vai se formulando "ao longo de um processo cumulativo de articulação com a sociedade e adensamento artístico" (Arantes \& Arantes, 1997, p. 21). Ou, de modo mais pormenorizado, evidenciando os elementos da formação nacional que estavam presentes nas escolhas estéticas dos autores, acaba por descobrir, em meio ao fato bruto da formação literária nacional, "o fio condutor de uma outra linha de força formativa, vir-a-ser de um sistema cultural que na sua trajetória ia aos poucos convertendo surtos desgarrados em vida literária efetiva”. Nesse sentido, Formação da literatura brasileira acabava dando outro passo importante: "aquela história de formação, que refundia de alto a baixo a interpretação de nosso passado literário, incorporava-se em termos atuais a um processo intelectual formativo de múltiplas dimensões”. Ou seja, olhando “apenas” a literatura, Antonio Candido acabou por entrar fundo no problema da formação (Arantes \& Arantes, 1997, p. 21-22).

Não por acaso, ao fim do processo de formação da literatura, há o surgimento de um escritor da importância e da profundidade de Machado de Assis, cujo reaproveitamento crítico dos acertos e erros de seus predecessores, bem como a sondagem da produção mais sofisticada da chamada literatura universal, permitiu, em seus romances maduros, que o escritor fluminense internalizasse as contradições e condições da sociedade brasileira do período (Candido, 2013). Ou seja, trata-se de enfrentar o problema da forma em uma 
país de formação difícil. Schwarz, por sua vez, mostra que em Memórias póstumas de Brás Cubas há uma estilização de uma conduta própria da classe dominante brasileira (Schwarz, 2012b). Nesse sentido, o crítico brasileiro passa a enfatizar algo inédito dentro dos estudos machadianos: a composição narrativa e formal da obra, em que destaca como a volubilidade é o princípio formal do livro.

Trocando em miúdos, a forma do romance machadiano formaliza implicações estruturais de um quadro histórico caracterizado, grosso modo, pela existência de três classes de população: o latifundiário, o escravo e o "homem livre" dependente. Entre as duas primeiras classes, a relação é da mais clara violência. Já quanto aos terceiros, o ponto é outro, pois nem escravos nem proletários têm seu acesso material aos bens mais variados da vida se não for por meio do favor de um grande. Sendo assim, o mecanismo a partir do qual se reproduz uma das classes da sociedade é o favor, o qual envolve também a classe dos que têm. É preciso notar que é entre essas duas classes que a vida ideológica irá girar e, assim, o favor passará a atravessar boa parte desta (Schwarz, 2012a). Favor, o qual é essencialmente caprichoso, volúvel e instável. Em suma, é da formação de uma forma literária adequada à realidade nacional - diversa, mas não alheia ao resto do mundo - que se trata. Assim, o que gostaríamos de indicar, tal como apontado por Ricupero, é a existência de um processo também de formação, que se completaria na forma, "até porque, como já afirmava o jovem Lukács em trabalho clássico sobre o tema, no momento em que a forma passa a existir há a 'conciliação do exterior e do interior"' (Ricupero, 2008, p. 64).

Ao nosso ver, essa dialética entre forma e formação perpassa e estrutura outras searas da produção artísticas no Brasil, como as artes visuais e o cinema. Tal dialética pode ser encontrada, em relação às artes visuais, em ensaios de Gilda de Mello e Souza (2008) e Rodrigo Naves (2011). A primeira, "atentando para os percalços, desdobramentos e resolução da dissonância entre a notação europeia e a realidade brasileira, fundamental para a estruturação interna da formação da pintura brasileira", e o segundo, "com sua escolha interpretativa, na qual a forma difícil, decantada no melhor da arte brasileira, é indicativa da constituição de uma forma adequada à experiência nacional diferencial" (Marino, 2017, p. 225), conseguiram ensaiar a forma como características essenciais da formação brasileira estruturaram e estruturam as artes visuais brasileiras. 
Argumentamos e procuramos demonstrar, neste artigo, que a experiência intelectual de Ismail Xavier também é estruturada por essa dialética entre forma e formação no Brasil. ${ }^{1}$ Isso se daria, na medida em que seu intento não seria outro que a pesquisa sobre as condições de formalização de uma forma cinematográfica que abarcasse, em sua estrutura formal, a formação social brasileira e, desde este ponto de vista, meditasse sobre e criticasse os pressupostos sociais e técnicos do cinema feito no centro do capitalismo. Sendo esse ponto de reflexão algo importante para a obra de Xavier, é nos ensaios sobre Glauber Rocha que isso se evidencia mais fortemente. Em nossa interpretação, isso ocorre porque, nos filmes do cineasta baiano, esse processo de formação de uma forma estética brasileira no cinema deu-se de forma mais densa e acabada - como veremos na exposição propriamente dita a respeito de Ismail Xavier.

Dessa forma, tomando emprestadas lições de Paulo Emílio Salles Gomes, Xavier identifica que a vontade dos brasileiros de ter um cinema nacional, enquanto sistema integrado, teria como ponto formativo os filmes de Glauber Rocha. Guardadas as devidas proporções, é como se o papel de Machado de Assis no esquema formativo de Candido fosse análogo ao de Glauber Rocha nos ensaios de Ismail Xavier sobre o cinema brasileiro. À vista do que foi dito sobre formação e forma, é possível, para nós, defender a ideia de que a categoria de formação é decisiva para que possamos apreender as determinações essenciais de produções e sistemas simbólicos variados produzidos, como as artes visuais, a literatura, as interpretações sobre o país e o cinema. Entraremos mais no assunto em questão, mesmo que de forma sucinta.

Ao nosso ver, o ponto focal formativo identificado por Ismail Xavier em Glauber Rocha se justifica pelo fato de que, em meio às preocupações de Rocha a respeito do cinema autoral - em contraposição ao cinema industrializado (Bernardet \& Reis, 2018) - e à revisão que fará da história do cinema a partir desse prisma, é notável sua preocupação com o Brasil e seu cinema, no concerto dos sistemas cinematográficos do mundo. O momento em que podemos localizar de maneira mais apurada essa preocupação com a constituição de uma tradição no cinema brasileiro é, principalmente, nos comentários que Rocha faz sobre a filmografia de Humberto Mauro (Rocha, 2003), quem teria sido a primeira figura do cinema nacional propriamente

${ }^{1}$ Iluminadores, nesse sentido, são os ensaios de Mendes (2019) e Saraiva (2019). 
dito - e não apenas do novo cinema no Brasil. Dessa forma, para o cineasta baiano, a obra de Mauro, com seus acertos e erros, seria o pressuposto fundamental para constituição de um cinema propriamente brasileiro. Assim, deixar de lado Humberto Mauro, para Rocha, seria uma espécie de suicídio, dado que, sem o espólio fílmico do primeiro, a feitura de um cinema brasileiro ficaria inviabilizada ou se tornaria uma espécie de viagem redonda de constituição cinematográfica, posto que as questões e resoluções formais não ganhariam ossatura e sistematicidade.

Trocando em miúdos, Humberto Mauro, para Glauber Rocha (2003), apareceria como uma forma especificamente eficaz e complexa de expressar um "sentimento íntimo" (Machado de Assis, 2015, p. 1179) de pertencimento ao Brasil. Assim, Rocha, de forma muito parecida com Machado de Assis na literatura, mostrava preocupação em entender o cinema no Brasil enquanto sistema, isto é, enquanto relação orgânica entre diretores/autores, público e uma linguagem constituída como tradição, a partir da qual se poderia tanto incorporar, formalmente, os traços distintivos da formação social brasileira quanto incorporar os influxos estrangeiros de maneira crítica - ou seja, sem cair num provincianismo, que não aceitaria o que é estrangeiro, nem num cosmopolitismo abstrato, a partir do qual modas intelectuais e artísticas ditariam o andamento da inteligência e das artes no Brasil.

Nesse bojo, é interessante ainda notar três elementos. Em primeiro lugar, essa visão de Glauber Rocha incorporava, com maior distanciamento crítico ou maior aproximação (a depender do caso), outras figuras além de Humberto Mauro, como Mário Peixoto, Walter Khouri, Linduarte Noronha, Paulo Saraceni e Joaquim Pedro de Andrade, cujo papel na seriação de um sistema do cinema brasileiro teria sido essencial. Em segundo lugar, Glauber Rocha, à vista disto, entroncava as suas obras - bem como as questões e resoluções estéticas delas constitutivas - nessa tradição de cinema, mostrando o seu empenho autoconsciente em levar a bom termo a formação de um cinema nacional. Em terceiro lugar, a formação de um cinema brasileiro, feito outras formações, tinha um caráter tanto retrospectivo quanto prospectivo. Isto é, legava um ponto de vista a partir do qual Rocha, quase como um crítico, poderia fazer uma revisão crítica do que fora efetivado no cinema nacional e estrangeiro e, da mesma forma, a partir do qual poderia elaborar as tarefas que o cinema brasileiro teria que enfrentar para acentuar sua relevância nacional e internacional - e manter a continuação de uma tradição. Todos 
esses elementos tornariam Glauber Rocha e sua obra um ponto focal decisivo para Ismail Xavier conseguir captar teoricamente o movimento de constituição de um cinema nacional, dotado de público, autores e uma linguagem artística própria, cuja solidificação deveria ser entendida como obra de gerações e que se transfiguraria numa espécie de filtro intelectual a partir do qual se poderia olhar a história do cinema brasileiro, e do mundo, e aproveitar, de forma crítica e sem modismos, as ideias e feitos internacionais. Como bem observa Saraiva (2019), feito Candido, o olhar de Ismail Xavier seria guiado por uma problemática, a formação do cinema brasileiro, o que lhe permite uma síntese original a partir de conhecimentos antes um pouco dispersos sobre o sistema do cinema brasileiro.

À vista do exposto, nos contrapomos a alguns críticos que estipulam uma forte obsolescência da categoria de formação para se pensar o Brasil e suas formas. Exploraremos alguns desses críticos e críticas a seguir.

Como ressalta Arruda (2017), a partir dos anos 2000, várias críticas e reinterpretações da categoria de formação passaram a ser feitas. Elas podem ser encontradas, por exemplo, em Alcides (2011), Arruda (2017), Arruda e Villarino (2016), Baptista (2005), Estrada (2015), Lage (2016), Nobre (2012, 2015) e Santiago (2014). Sem pretensão de ser exaustivos, passaremos por alguns pontos presentes nos autores a que se fez referência e, posteriormente, procuraremos estabelecer um diálogo crítico com estes. ${ }^{2}$ Sabemos que tais críticos possuem diferenças sensíveis entre si. Porém, isso não está em jogo em nosso argumento, visto que exporemos as suas contribuições sobre a formação e sobre essas contribuições é que nos debruçaremos. Dessa forma, não intentamos produzir uma interpretação global a respeito de suas obras, mas sim questioná-los a partir de um ponto de vista muito preciso, a saber: a maneira como encararam a questão da formação. Justificamos, dessa maneira, a um só tempo, o tratamento dispensado aos seus argumentos e o fato de não termos, necessariamente, que adentrar em outros textos e ensaios dos quais são autores. ${ }^{3}$

\footnotetext{
${ }^{2}$ Quanto a um autor como Abel Barros Baptista (2005), não nos demoraremos na discussão. Basta indicar que o autor português vê erroneamente o livro Formação da literatura brasileira como uma teoria da literatura brasileira, logo carregada de grande normatividade. Na verdade, o livro de Candido volta-se muito mais para uma análise imanente das forças essenciais à constituição de um sistema literário no Brasil e sua problemática interna. Dessa forma, não se trata de uma preferência nacionalista de Candido e uma normatividade disso decorrente. ${ }^{3}$ Até porque, salvo engano, todo trabalho intelectual de crítica que não fosse centrado em um único
autor ou obra ganharia fortes constrangimentos ou poderia se perder em digressões sem crítica.
} 
Sérgio Alcides (2011) procura enfatizar em seu artigo a existência dos termos "momentos decisivos" como algo não gratuito no título de Formação da literatura brasileira. Ressalta o "decisivo" da construção cujo ponto de fuga, em sua visão, seria uma urgência em constituir um corpus teórico que sedimentasse a experiência intelectual acumulada no Brasil por via literária, antes que a indústria cultural a removesse de cena e a destruísse. Além disso, por trás desse esforço, haveria um desejo ou expectativa da constituição de um novo "momento decisivo", que "revertesse uma tendência forte à desorganização dos esforços civilizacionais acumulados, com o seu consequente desperdício" (Alcides, 2011, p. 148). Referindo-se ao termo "momento", Alcides o vê quase como um elo entre os projetos intelectuais de Silvio Romero e Antonio Candido em ligarem literatura e nacionalidade. Procedimento nacionalista e que teria perdido sua razão de ser, juntamente com o ponto de vista formativo, dado que o atual estágio da globalização ou internacionalização do mundo levaria a uma perda de importância da dinâmica interna ao país.

Silviano Santiago (2014), por sua vez, seguindo uma análise que, em linhas gerais, lembra a de Alcides, ressalta que Candido e sua Formação da literatura brasileira teriam sido, a partir da segunda metade do século 20, essenciais para a formação de qualquer estudante de letras e humanidades no Brasil. Contudo, a partir de críticas embebidas em teorizações póscoloniais, critica a argumentação de Candido, por essa ter sido uma espécie de vacina ocidentalizante responsável pela imunização da literatura e do pensamento nacional frente ao que era feito e pensado em outras excolônias portuguesas.

Mas como Santiago teria sido afetado pelo que chama de virose pós-colonial, não tendo sido protegido pela vacina ocidental-nacionalista de Candido? A resposta, apesar de idas e vindas, aponta para uma tradicional experiência profissional e educativa internacionalizada, passando pelo conhecimento de teóricos franceses, um doutoramento na França e aulas dadas no México. Tal período de aprendizado foi, finalmente, traduzido em método intertextual pelo autor, ao procurar em textos canônicos da época colonial e em textos mais modernos metáforas repletas de carga semântica, as quais indicariam, num primeiro momento, manobras eficientes do colonizador e que, depois, seriam utilizadas com carga francamente anticolonial. Nessa mesma toada, poder-se-ia compreender a constituição da noção de “entrelugar”, importante 
para relativizar categorias por demais estanques de originalidade e cópia, além de permitir, por via de uma leitura intertextual, inovações e variâncias. E, de quebra, ainda serviria para relativizar discursivamente outra dupla de categorias consideradas estanques: centro e periferia.

Subjacente a tais argumentos, está a ideia, próxima à de Alcides (2011) - apesar de este ser mais reticente quanto à ideia de integração global do Brasil -, de que novas condições materiais passam a exigir outro conjunto de discursos e um novo paradigma para o país: o da inserção do Brasil no mundo globalizado. Ou melhor, como a nação agora é cosmopolita, seria urgente a inserção da literatura brasileira em contexto universal, possibilitando a revelação de que problemas antes tomados como locais tinham verdadeira dimensão internacional. Em outras palavras, a dinâmica interna do país deixaria de ser importante e, consequentemente, os discursos da formação se encontrariam esgotados.

Victor Coutinho Lage (2016), em certo sentido, também se aproximará do quadro conceitual utilizado por Alcides e Santiago, procurando reinterpretar as chamadas interpretações do Brasil, a partir de um arcabouço teórico pós-colonial e mesmo pós-estruturalista. Chama a atenção no estudo de Lage a amplitude que a categoria de formação toma, abarcando autores como Raymundo Faoro, Oliveira Viana, Nelson Werneck Sodré até Antonio Candido e Florestan Fernandes. O que também se torna um problema, pois, especificando-se pouco, a tentação por passar ao largo das diferenças dos autores é grande e incorre numa equalização não tão bem explicada entre eles. Tais intelectuais passam pelo crivo categorial de Foucault, Derrida e autores do que ficou conhecido como Subaltern Studies, interpretados a partir do que chama de traços linguísticos. Lage sugere que a literatura sobre formação incorreria em duas posturas: (i) performances aporéticas, dado que teriam em si tanto perspectivas modernizantes quanto críticas à própria modernização, e (ii) a indicação de ausências discursivas importantes, assentadas em narrativas decorrentes do processo incompleto de passagem da colônia para a nação moderna, das desigualdades internas e da mobilização de parâmetros importados para análise nacional. Não obstante, o autor argumenta que, lidas como obras contemporâneas, essas interpretações poderiam criar um lugar interpretativo potencial importante para a problematização da modernidade, desde que fossem abordados os elos entre as deformidades supostamente nacionais e o processo social global. 
Já para Nobre (2012, 2015), entre as ditaduras de Getúlio Vargas (19371945) e a militar (1964-1985), estabeleceu-se uma vertente hegemônica no interior do campo mais amplo da versão democrática do projeto nacionaldesenvolvimentista, cuja palavra de ordem era "formação". O programa por trás dessa expressão preveria a tentativa de vincular modernização e democracia, justiça social e modernidade, além de criticar a versão autoritária do projeto nacional-desenvolvimentista. De modo, portanto, a compatibilizar, a um só tempo, um desenvolvimento o mais autônomo possível - baseado em um mercado interno relevante, capaz de superar a nossa condição de subordinação - e uma modernização entendida como combate aos diferentes arcaísmos. Compreendia-se, desde essa perspectiva, que, na ausência dessas condições, uma nação autônoma e uma democracia substantiva seriam impossíveis no Brasil.

De acordo com o filósofo paulista, outro fator essencial para a consolidação do programa e da palavra de ordem em questão seria a universidade. Em especial, constituir-se-ia uma disciplina filosófica passível de construir uma autocompreensão moderna do país, capaz de identificar as raízes dos arcaísmos a serem enfrentados. Essa forma de fazer filosofia teria como adversária um conjunto de filosofismos locais, baseados em uma concepção da atividade filosófica sem rigor conceitual ou como aparentada de outras disciplinas, como o direito e a teologia. Essa forma de pesquisa filosófica lastreada no que o autor chama de paradigma da "formação" teria ganho a disputa e passado a ser hegemônica. Ademais, fazia parte de um consórcio intelectual maior, no qual outras disciplinas e artes eram responsáveis por pensar o Brasil e sua modernização. Restaria estabelecer melhor o lugar da filosofia, fazendo com que ela não se limitasse a ensinar história da filosofia, mas conseguisse produzir um pensamento autônomo e próprio. Essa hegemonia teria se completado pós-golpe de 1964, evento que tornaria necessários novos diagnósticos críticos, chamados por Nobre de momento reflexivo. Este corresponderia aos textos Crítica à razão dualista, de Francisco de Oliveira, Ao vencedor as batatas, de Roberto Schwarz, e Trabalho e reflexão, de José Arthur Giannotti. Os quais, cada um a seu modo, mostrariam o imbricamento necessário e real entre o "arcaico" e o "moderno", no qual este último termo reporia o primeiro.

Não obstante, esse momento de maturidade filosófica teria coincidido com mudanças estruturais do capitalismo, que inviabilizavam qualquer 
projeto nacional-desenvolvimentista dependente de padrão tecnológico estável de produção nos países centrais - diagnóstico próximo ao de Cardoso e Faletto (2011) - além de pôr fim às possibilidades de financiamento. Em outras palavras, o que Nobre chama de paradigma formativo dependeria inextrincavelmente do nacional-desenvolvimentismo e seu projeto de país, pensado como unidade autônoma. Já nas condições pós-redemocratização e posteriores à reconfiguração do capitalismo internacional, segundo o autor, um "projeto de país" só poderia ser pensado a partir de uma ampla luta social e política, dentro e fora do Estado, permeada por diferentes conflitos entre diversas constelações hegemônicas. Tal situação tornara, consequentemente, projeto e paradigma inviáveis e caducos. Com base nesse diagnóstico, o filósofo propõe, por assim dizer, outro projeto e outro paradigma, os quais correspondem a uma nova lógica das redes, que se imporia como princípio de organização da produção material e cultural mundial, mudando o vínculo tradicional entre "centro" e "periferia”.

Estrada (2015) entende, por sua vez, a categoria de formação como construção simbólica. Para o historiador, a categoria de formação utilizada pela historiografia nacional poderia ser comparada com o conceito de bildung, emprestado da filosofia alemã e dos romances de formação, ao modo de Os anos de aprendizado de Wilhelm Meister, de Goethe. Estrada argumenta que nos romances de formação é o sentido de uma vida que está em jogo. Já para os historiadores brasileiros a individualidade ali tratada é a nação. Assim, Caio Prado Jr., Celso Furtado e Sérgio Buarque de Holanda sugeririam, em temos até romanescos, a ideia de uma nação problemática e das suas possibilidades no futuro. A categoria de formação operada pelos autores apontaria, para além de análise objetiva, um modo específico de configuração da realidade histórica, ou melhor, ela deveria funcionar como uma "forma simbólica" manejada por intérpretes que buscavam dar coerência narrativa às suas concepções de nacionalidade problemática. Ao final da exposição, Estrada aponta a diluição dessa forma simbólica em prol de novas narrativas e autoridades disciplinares.

Já Arruda e Villarino (2016), ao também enfatizarem a dimensão simbólica da "formação", atentarão mais ao trabalho de Antonio Candido e o interpretarão a partir do prisma da arqueologia foucaultiana e da teoria do simbólico na linguagem de Lacan. O que os faz considerar a obra de Candido como um giro linguístico em meados do século 20, que prefiguraria, em ao 
menos duas décadas, o chamado cultural turn. Ainda de acordo com essa leitura, Formação da literatura brasileira seria um livro moldado pelo desejo de Antonio Candido, "que transformou o desejo de formação em objeto, sendo, por isso, uma 'história do desejo desejado”" (Arruda \& Villarino, 2016, p. 16).

Seguindo argumento de Salete Cara (2014), é possível ver ainda aqueles que tiram como lição essencial da formação uma espécie de celebração de nossa especificidade local ou de nossa brasilidade. Dentre esses, um exemplo destacado é o de José Miguel Wisnik. O autor, em seu Veneno remédio (2008), argumenta que Antonio Candido e sua obra conseguiriam trazer para o pensamento uspiano - por demais assentado numa ideia pessimista sobre o Brasil - certo elogio de nossa particularidade. Ao final do livro, Wisnik argumenta que a formação "não poderia se dar apenas na literatura: o ser brasileiro pede minimamente - para se expor em sua extensão e intensidade - a literatura, o futebol e a música popular" (Wisnik, 2008, p. 405). De modo mais normativo, a experiência brasileira poderia tanto ser interpretada em termos de veneno como de remédio. Dessa forma, esses polos negativo e positivo apareceriam em Caio Prado Jr. - analista de nosso atraso como veneno patológico - e Gilberto Freyre, - que destacaria a dimensão de remédio, em função da ambivalência da civilização mestiça e original gestada nos trópicos. De posse dessa tipologia, Wisnik critica a produção de Paulo Arantes e Roberto Schwarz, considerando o ponto de vista desses autores como por demais pessimista, devedores profundos do paradigma negativo de Prado Jr. Para levar a cabo sua interpretação a respeito de Candido, lança mão das partes finais do ensaio de Candido Dialética da Malandragem, em que o crítico literário argumenta que, no Brasil, a atitude de tolerância quase corrosiva e de uma acomodação geral que dissolve os extremos, abre caminho, em comparação com os Estados Unidos, puritano e punitivo, para uma atitude aberta e afim a um mundo democrático e emancipado (Candido, 2013).

Sem ter a pretensão nem de ter esgotado o argumento dos autores apresentados e menos ainda de responder a esses sistematicamente, passaremos agora a algumas considerações críticas de seus argumentos, além de, por último, lançarmos mão de uma certa visão sobre o ponto de vista da formação.

É possível que depreendamos do argumento de Wisnik (2008) um processo distinto do que ele mesmo propõe para que se compreenda de modo mais 
complexificado o Brasil. Ou seja, apesar de o autor argumentar que uma visão mais completa sobre o país conjugue tanto o positivo quanto o negativo - o remédio e o veneno - pode-se perceber que ele acentua a dimensão positiva. Isso porque, ao eleger nossa sociabilidade como necessariamente plástica e como possível via para um mundo mais democratizado, Wisnik desistoriciza a experiência social efetiva, uma vez que, como ele mesmo argumenta sem tirar todas as consequências - a dialética da malandragem pode e é reaproveitada de modo bárbaro no Brasil e no mundo. Por conseguinte, certo culturalismo pode contribuir para mascarar os conflitos presentes no processo socio-histórico, contribuindo, como sugere Cara (2014), para um horizonte de conciliação de classes e de integração acrítica no mundo globalizado. Ademais, esse elogio de nossas particularidades culturais ou nacionais pode potencializar processos regressivos importantes. De forma mais destacada, essa celebração do particular perante o universal pode levar não a uma crítica da modernidade, mas, conforme argumento de Chibber (2013), reproduzir, de modo invertido, instâncias da mitologia orientalista. Isto é, nessa ênfase, pode-se notar a restauração de uma visão exótica da periferia do capitalismo em geral e do Brasil em particular. Podemos perceber, nessa referência, uma tensão interna ao esquema argumentativo de Lage (2016), pois, ao mesmo tempo em que se serve do arcabouço conceitual pós-colonial e concorda com a potencialidade da tradição crítica brasileira, deixa de lado diferenças importantes entre ambos, visto que, se a tradição crítica persegue a especificidade nacional, o faz com o intuito de vê-la em meio ao processo social mundial do capitalismo; pós-coloniais, em contraste, louvam o específico e o local, impedindo o estabelecimento dos nexos críticos próprios da relação entre centro e periferia mundial.

Inspirando-nos nos argumentos de Otília Arantes (1997a, 1997b) e Cara (2014), podemos argumentar que nossa "diferença” cultural, em suas mais diversas manifestações, entra como mais uma mercadoria no mundo globalizado. Otília Arantes defende, em especial, que, ao se transplantar para cá a arquitetura nova - dotada, em sua origem, de pressupostos materiais os mais avançados do mundo capitalista - e esta ter dado um salto qualitativo mundialmente reconhecido, ficaria indicada a falência da ideologia arquitetônica mundial. Isso porque, em linha gerais, ela prometia, por meio da racionalização e funcionalização das formas e, portanto, dos projetos e obras, certa fé nas virtualidades democráticas da produção em massa 
(Pedrosa, 2004), colocando na ordem do dia uma vida transparente quanto às suas potencialidades e necessidades, ou seja, uma vida emancipada (Le Corbusier, 2004; Xavier, 2003).

$\mathrm{O}$ transplante na periferia brasileira geraria um verdadeiro desencontro entre doutrina e pressupostos sociais, o qual revelaria algo não percebido no centro capitalista: que a arquitetura nova e seu desenvolvimento poderia não passar de um jogo abstrato de formas ligado ao movimento do capital. Todavia, bem ou mal, a tradição modernista nacional sempre alimentou a fantasia de estar na vanguarda da integração das classes populares na construção nacional. Com a mundialização radical do capital, essa utopia foi relegada aos museus das ideologias passadas. Mesmo assim, o arquivo morto arquitetônico passaria a ser incorporado à ideologia do caráter nacional brasileiro, num movimento de sublimação cultural do retrocesso civilizacional.

Na mesma toada, é lícito perceber nos argumentos de Nobre (2012), Santiago (2014) e, em menor potência, Alcides (2011), uma ideia-força de integração do Brasil no mundo, seja por meio de redes, seja por uma inserção cosmopolita incerta. Não obstante, vemos alguns problemas nessa argumentação. Apesar de embocaduras teóricas e epistêmicas distintas, os diagnósticos de época expostos pelos três autores aproximamse consideravelmente entre si e com a interpretação desenvolvida por Fernando Henrique Cardoso dos anos de 1960 em diante. Nesse período, Cardoso (1967, 1971, 1972; Cardoso \& Faletto, 2011) propunha a ideia de que houve mudanças estruturais no capitalismo internacional, levando a um abandono necessário de projetos voltados para a integração dos países periféricos como nações autônomas, economicamente independentes, socialmente coesas e modernas sob hegemonia da burguesia nacional. Num terreno comum, Alcides, Nobre e Santiago veem como saída necessária para o pensamento e para o Brasil a sua inserção nas redes e nas cadeias produtivas internacionais das ideias.

Ora, salta aos olhos, também, a associação entre formação e desenvolvimentismo ser dada de saída e de modo simplificado. Segundo nosso ponto de vista - baseado em Schwarz (2014) e Cevasco (2014) -, o período anterior ao golpe de 1964, até pelo menos a promulgação do Ato Institucional número cinco (AI-5), compreende um momento histórico de rara desprovincianização intelectual e agitação política à esquerda. Um momento histórico conhecido como desenvolvimentista, no qual armou- 
se um imaginário social novo, que está relacionado, mas não é sinônimo, com o ponto de vista da formação. Isto é, a não realização das promessas de desenvolvimento integrado não invalida aquilo que foi pensado a partir da formação, na verdade torna o ponto de vista da formação mais necessário. Mesmo autores como Prado Jr. e Celso Furtado, que escreveram suas obras com o intuito de levar a bom termo a construção nacional, formularam uma análise imanente ${ }^{4}$ da realidade brasileira, em que enfatizam a condição periférica do país. De sorte que abandonar seus ensinamentos, como se pudéssemos passar a ser, sem maiores problemas, cidadãos do mundo, levaria a um cosmopolitismo meramente abstrato.

Quanto à dimensão simbólica, acentuada por Arruda, Villarino e Estrada, é interessante perceber que procuram, de modos distintos, escandir nas obras da formação quase que apenas as escolhas infrarracionais de seus autores. ${ }^{5}$ Com efeito, o ponto de vista formativo seria uma forma possível, dentre outras baseadas em variadas narrativas que buscariam configurar a realidade histórica brasileira. Em sentido oposto, defendemos que as análises empreendidas pelos ensaístas tratados neste artigo efetuavam uma crítica imanente da realidade, apreendendo as determinações essenciais desta e suas potencialidades de mudança. Ademais, caso o ponto de vista formativo fosse uma escolha narrativa possível a respeito da história brasileira, quais seriam os nexos que permitiriam que esta fosse a doxa dominante do pensamento nacional? É interessante que não expliquem tal difusão. Estrada (2015), por seu turno, chega mesmo a afirmar que essa forma de narração não teria objetividade científica. O autor, em compensação, já possui, de antemão, um paradigma objetivo e científico claro, algo que tornaria a busca por outros paradigmas e autoridade disciplinares - ponto de fuga caro ao seu texto - uma tarefa sem fundamento claro. Isso nos leva a acreditar que mais produtivo seria não emprestar categorização alheia para melhor entender e criticar a tradição crítica brasileira, mas aproveitar o pensamento dessa linhagem para se pensar e passar pelo crivo da experiência efetiva as categorias importadas (Arantes, 1991; Schwarz, 2014).

\footnotetext{
${ }^{4}$ Por análise ou crítica imanente entendemos o ponto de vista a partir do qual se tenta analisar o objeto nele mesmo, em suas determinações essenciais, e no qual a primazia é o objeto mesmo e seu movimento e não sua comparação em relação a padrões teóricos externos a ele (Hegel, 2012).

${ }^{5}$ Quanto a essa designação, a emprestamos da crítica feita por Gérard Lebrun (1988) a Hegel em O avesso da dialética. Seguindo alguns ensinamentos de Nietzsche, o filósofo francês volta seu martelo para as escolhas infrarracionais do discurso hegeliano, procurando mostrar por esse caminho que o discurso do filósofo alemão não manteria a promessa da imanência.
} 
Seja como for, ao nosso ver, a categoria de formação, mesmo com uma série críticas, mostra-se decisiva para que possamos entender a formação de formas e de sistemas simbólicos que dessem conta, formalmente, da estrutura social brasileira. Tal imbricamento entre formação e forma foi decisivo para a experiência intelectual de Ismail Xavier e é o que pretendermos mostrar na próxima seção.

\section{Lineamentos sobre Ismail Xavier: sertão, mar e forma}

O crítico de cinema Ismail Xavier enfrenta problemas parecidos aos de Schwarz ${ }^{6}$ e Naves quanto à relação entre forma e processo social à brasileira. O crítico, como ele mesmo indica (Xavier, 2013), teve tanto uma formação extra-acadêmica, frequentando cineclubes, quanto acadêmica, passando pela Escola de Comunicação e Artes da Universidade de São Paulo (ECA-USP), pela Faculdade de Filosofia, Letras e Ciências Humanas da Universidade de São Paulo (FFLCH-USP) e pela Universidade de Nova York. De qualquer forma, a passagem por essas instituições foi fundamental para sua formação, pois o colocou, por exemplo, em contato com Antonio Candido e Paulo Emílio Salles Gomes e com uma bibliografia especializada sobre crítica cinematográfica.

Segundo Xavier, foi com Salles Gomes - uma das maiores referências críticas no Brasil sobre cinema - que passou a tomar gosto pela crítica e pelo campo da reflexão cinematográfica mais do que por sua feitura. Juntamente com Antonio Candido, o crítico cinematográfico ensinou-lhe uma postura que enfatizava o corpo a corpo minucioso com os objetos de estudo. ${ }^{7}$ Dessa forma, passou a acreditar que toda teoria deveria ser testada quando do enfrentamento com o objeto, demonstrando ter, assim, uma potência explicativa ou não. Isto é, a teoria deveria ser mobilizada a partir da problemática fílmica, devido às demandas trazidas pela análise e não num

\footnotetext{
${ }^{6}$ É interessante notar que Xavier (2007a) possui um texto sobre Schwarz em que irá se concentrar nos ensaios do crítico literário sobre cinema: "O traço comum aos três ensaios [de Schwarz] é a procura do que, nos filmes, constitui a marca indelével do contemporâneo e permite problematizar o estatuto da imagem no tecido das relações de poder em cada um dos contextos sociais postos em foco" (2007a, p. 214).

${ }^{7}$ Segundo o crítico: "A tarefa da crítica muitas vezes envolve o gesto fundamental de apontar a diferença entre projeto, intenção e realização, pois é a obra que cria o autor e não o contrário" (Xavier, 2007, p. 9).
} 
"movimento de aplicar mecanicamente ou fazer da obra uma ilustração de um ponto de vista teórico” (Xavier, 2013, p. 217). ${ }^{8}$

É de crítica imanente que fala Xavier e é o que seus mestres - apesar de suas diferenças - haviam lhe ensinado, o que o aproxima das experiências críticas de Schwarz e Naves. ${ }^{9}$ Tal forma de crítica é desenvolvida por meio de uma ensaística, a qual, nas palavras de Xavier, "explora uma problemática que você define e que vai se construindo através de um jogo de interpretações, que pode passar por conceitos que são fundamentais, mas desde que esses conceitos se mostrem efetivamente produtivos na lida com aquilo [com o objeto]" (2013, p. 218). Outro polo que se apresenta como fundamental a Xavier é a história. Segundo o crítico de cinema, o ideal é que a grande crítica consiga abarcar de modo satisfatório esses três elementos, aproximando-se decisivamente dos críticos anteriormente elencados.

Resumindo, há o quadro conceitual, há a interação com o objeto no sentido de uma resposta valorativa, pois a crítica implica juízo, e, ao mesmo tempo, há a história como, digamos assim, o solo a partir do qual tudo se faz. Porque a história, para mim, é a premissa. Não sou historiador, mas, para mim, a história é o solo a partir do qual você pode pensar as coisas. Uma experiência se dá no tempo e dentro de um processo que tem um dinamismo, com o qual você tem de lidar num trabalho sobre arte. Crítica, teoria e história são três dimensões que vão se combinar, com pesos distintos, conforme eu esteja fazendo análise de filme ou um panorama (Xavier, 2013, p. 228).

A mesma imbricação entre processo social e forma, que dá as caras sistematicamente na crítica também dialética de Schwarz e Naves.

Dando continuidade ao nosso argumento, segundo um dos mestres de Xavier, Paulo Emílio, ${ }^{10}$ a situação do cinema brasileiro seria de subdesenvolvimento.

O cinema norte-americano, o japonês e, em geral, o europeu nunca foram subdesenvolvidos, ao passo que o hindu, o árabe ou o brasileiro nunca

\footnotetext{
${ }^{8}$ Postura que aproximamos com aquela do antigo grupo Clima, cuja motivação vinha do professor Jean Maugüé (Arantes, 1994).

9 “Ismail enfrenta a questão com as armas na análise imanente, especificando-a pela atenção às filigranas da composição estética das obras, em suas transformações internas, e na comparação com os arranjos formais dos filmes. Pelo cotejo [...] o crítico caracteriza o primeiro estilo glauberiano [...]" (Saraiva, 2019, p. 145-160).

${ }^{10}$ Sobre a vinculação entre o crítico em questão e um pensamento radical, galvanizado por um marxismo heterodoxo e democrático ver Gomes (1986) e Candido (1986).
} 
deixaram de ser. Em cinema o subdesenvolvimento não é uma etapa, um estágio, mas um estado: os filmes dos países desenvolvidos nunca passaram por essa situação, enquanto os outros tendem a se instalar nela. O cinema é incapaz de encontrar dentro de si próprio energias que lhe permitam escapar à condenação do subdesenvolvimento, mesmo quando uma conjuntura particularmente favorável suscita uma expansão na fabricação de filmes (Gomes, 2001, p. 85).

No entanto, apesar de traços de semelhança entre as situações cinematográficas subdesenvolvidas, a brasileira não se encontraria num terreno cultural diverso do ocidental, de sorte que, ao sermos um prolongamento do Ocidente, não teríamos uma personalidade cultural totalmente diversa, não nos tornando propriamente ocupados. Tanto é que, quando o ocupante ${ }^{11}$ aqui chegou, o ocupado foi quase completamente extirpado, criando-se um novo ocupado, mais ou menos à imagem ou semelhança do ocupante. Trocando em miúdos, não seríamos nem americanos nem europeus, todavia não possuiríamos uma cultura original ou autóctone: "nada nos é estrangeiro, pois tudo o é [...]”. Reverberando em uma construção que se desenvolveria em uma "dialética rarefeita entre o não ser e o ser outro” (Gomes, 2001, p. 90). Tal condição seria inescapável para o cinema, mas também criaria traços próprios, dada nossa incompetência congênita em copiar, o que geraria um resultado distinto do modelo formal inicial, geralmente estadunidense e, num punhado de vezes, europeu. Os resultados, por vezes, seriam bons, já que seriam criadores de diferenças e novos significados, mas também poderiam ser bastante ruins e amadores.

Interessante notar que o cinema, inventado em países desenvolvidos, chegou rapidamente ao Brasil. Em 1908, a capital federal, Rio de Janeiro, conheceu um período importante de produção fílmica, chamada de Belle Époque, que chegou mesmo a contar com a prevalência, em termos de bilheteria, de filmes nacionais sobre estrangeiros. Porém, com o início da produção fílmica em escala industrial nos países centrais, somado ao ímpeto de importação presente no Brasil, a nossa incipiente tentativa de criação de um cinema nacional foi abortada. Já nos anos de 1940, o cinema voltou a se desenvolver no Rio de Janeiro, com musicais e chanchadas,

\footnotetext{
${ }^{11}$ Os temos ocupante e ocupado são utilizados por Paulo Emílio Salles Gomes e podem ser entendidos como quase sinônimos, respectivamente, de colonizador e colonizado.
} 
espetáculos que emanavam diretamente de uma espécie de fundo brasileiro. Assim se estabeleceria entre os filmes e os espectadores "um fato cultural incomparavelmente mais vivo do que o produzido até então pelo contato entre o brasileiro e o produto cultural norte-americano" (Gomes, 2001, p. 95). Até porque, no último caso, o envolvimento era passivo e de mero consumo, enquanto com o cinema brasileiro haveria elementos de criatividade e de criação de polêmica entre ocupados e ocupantes. Experiência também tentada em São Paulo, que, contudo, fracassa por seu caráter estritamente comercial e sem vinculação com a veia popular. Mesmo que não alterasse efetivamente o desequilíbrio entre os interesses nacionais e os estrangeiros, esse segundo momento carioca assegurou a possibilidade de respiro para o cinema ficcional.

Respiro o qual foi alimentado mais ainda por uma vaga e difusa cultura de esquerda na qual os comunistas, apesar de sua ortodoxia, tinham papel importante (Schwarz, 2008). Encorajava-se então um engajamento artístico voltado à vida popular, principalmente urbana. O antigo herói de chanchada e o malandro davam lugar ao trabalhador, as tramas menos complexificadas dos dois momentos anteriores sairiam de cena e entraria uma construção dramática mais consistente, influenciada pelo neorrealismo italiano e próxima à literatura do modernismo tardio. Daí se desenvolveu o Cinema Novo, conseguindo-se, a partir desse momento, criar uma imagem coerente do povo brasileiro e de sua fome.

Todavia, esse processo foi interrompido em 1964. As alegorias - conceito referência que permeia boa parte da melhor produção fílmica nacional - e o sentido da teleologia, a qual acaba por condensar bem as noções de todo e partes nas películas, mudam sensivelmente. ${ }^{12}$ Nos anos 1960, mesmo com a alegoria tendo uma textura de imagem e som descontínua, a história ainda é pensada como teleologia e a ordem do tempo, dotado de razão e com uma marcha em direção a um télos, é plasmada a partir da certeza da revolução, que organiza e dá sentido ao que é vivido. Como em Deus e o diabo na terra

\footnotetext{
12 Para uma discussão mais pormenorizada sobre o conceito de alegoria, bem como sua produtividade na discussão fílmica e das artes, ver Xavier (2012). Segundo a tradição clássica, a alegoria traria consigo a ideia de falar uma coisa referindo-se a outra, marcando uma fratura entre o espírito e a letra, entre o que é manifesto e um sentido não explicitado e até disfarçado no discurso, "havendo a mediação reconhecida de uma convenção que se interpõe entre a fala e a experiência, em outras palavras, a mediação da espessura própria da linguagem em sua relação problemática com o mundo" (Xavier, 2012, p. 447).
} 
do Sol (1963-1964), no qual o fim é a salvação, a luta por um mundo melhor é entendia como própria da vocação humana e a esperança é sistematicamente reafirmada. Tudo isso amparado pela ideia de que a violência revolucionária seria um elemento de suma importância para a superação da condição subalterna e da constituição de um projeto de nação autônoma, ou seja, da formação da nação. Essa seria uma construção própria ao período pré-golpe de 1964, de esperanças civilizatórias e revolucionárias exacerbadas.

Dado o golpe, as grandes esperanças tornam-se ilusões perdidas: as alegorias expressam, a partir daí, uma crise da teleologia e sua negação mais radical. Chega-se até a figurações audiovisuais apocalípticas, como é caso de boa parte da filmografia forjada no chamado "Cinema do Lixo", nas quais há a negação de qualquer possibilidade de salvação e em que a antiteleologia ${ }^{13}$ funciona como princípio agressivo essencial para a organização da experiência.

Nesse bojo, é interessante observar uma postura de crítica e abandono da ideia de que o cineasta deveria ser tomado como porta-voz de uma nação ainda não formada. Reconhece-se que boa parte de seu público pertencia à classe média universitária e intelectualizada, de sorte que aí há uma internalização da questão da crítica do público, com o uso das chamadas estratégias de agressão e a busca por experiências de choque. ${ }^{14}$ Representantes importantes dessa ruptura são os filmes Terra em transe (1967), de Glauber Rocha e o Bandido da luz vermelha (1968), de Rogério Sganzerla, os quais representariam a passagem histórica da “estética da fome” para uma "estética

\footnotetext{
${ }^{13} \mathrm{O}$ par teleologia e antiteleologia é importante na análise que Xavier (2007b, 2012) faz do cinema glauberiano. Em filmes como Barravento e Deus e o Diabo na terra do Sol, a partir do que diz Xavier, é possível notar uma lógica de totalização profética e revolucionária que organizaria, sem apagamento, os fragmentos fílmicos e que teria um sentido teleológico cujo fim era a libertação popular e nacional no Brasil. Com o golpe militar de 1964, esse télos de libertação nacional sai do campo político e estético, de modo que o princípio organizador dos chamados filmes tropicalistas, como Terra em transe e O bandido da luz vermelha (de Sganzerla), seria o da antiteleologia, que era galvanizada pela consciência política e estética do fracasso de uma saída nacional-popular e pela crítica à modernização conservadora brasileira - bem como seu caráter kitsch. Essa antiteleologia se manifestava formalmente por meio de uma alegoria do desengano, na qual a paródia, a ironia, os choques constantes, a luta contra a inteireza e a descontinuidade são decisivos. Para mais, ver Mendes (2019), Saraiva (2019) e Xavier (2013).

14 Procedimentos os quais, ao nosso ver, podem ser também encontrados no período de radicalização do teatro, por exemplo, como é o caso do Teatro Oficina. Nesse diapasão, em entrevista de 1968, Zé Celso Martinez Corrêa (1998) identificará o filme Terra em transe como uma peça política necessariamente agressiva e violenta, principalmente em relação ao público de classe média. Tal público, na visão do dramaturgo, deveria ser violentado, chamado de recalcado e reacionário e ter seus mecanismos de defesa destruídos, dado que, esse setor seria um dos que mais se beneficiaria da barbárie brasileira.
} 
do lixo" (Xavier, 2013, p. 36), marcando uma crise da teleologia e abrindo espaço, principalmente com o filme de Sganzerla, para outras posturas. Em filmes como $O$ dragão da maldade contra o santo guerreiro (1969) e Macunaíma (1969), respectivamente de Rocha e Joaquim Pedro de Andrade, apresenta-se uma antiteleologia temática ou de organização do conteúdo, mas com alegorias de fundo pedagógico e que marcam a existência de uma identidade nacional que se relaciona com a modernização conservadora. Finalmente, a antiteleologia se torna princípio formal efetivo - ordenando o estilo de representação e a existência de um questionamento profundo do próprio processo narrativo e seu esquema pautado em começo-meiofim -, procedimento notado em filmes como O anjo nasceu (1969), de Júlio Bressane.

De todo modo, é preciso dizer que o nosso intento aqui não é passar pela análise de toda essa filmografia listada e sim por alguns filmes de Glauber Rocha. Isso porque, na obra desse diretor, poder-se-ia perceber de modo mais acabado a transfiguração da matéria brasileira em forma fílmica.

É sugestivo notar que o subtítulo do livro Sertão Mar de Xavier é Glauber Rocha e a estética da fome. O primeiro termo dispensa maiores apresentações. Já o segundo poderia deixar o leitor um tanto quanto intrigado, não pela existência de fome no Brasil, mas em razão da preposição "sobre” não estar no lugar da preposição "da" - afinal de contas vários filmes dessa época retratam a situação de pobreza e carestia. De acordo com Xavier,

da fome. A estética. A preposição “da”, ao contrário da preposição "sobre", marca a diferença: a fome não se define como tema, objeto do qual se fala. Ela se instala na própria forma do dizer, na própria textura das obras. Abordar o cinema novo do início dos anos 60 é trabalhar essa metáfora que permite nomear um estilo de fazer cinema. Um estilo que procura redefinir a relação do cineasta brasileiro com a carência de recursos, invertendo posições diante das exigências materiais e as convenções de linguagem próprias do modelo industrial dominante. A carência deixa de ser obstáculo e passa a ser assumida como fator constituinte da obra, elemento que informa a sua estrutura e do qual se extrai a força da expressão, num estratagema capaz de evitar a simples constatação passiva "somos subdesenvolvidos" ou o mascaramento promovido pela imitação do modelo imposto que, ao avesso diz de novo "somos subdesenvolvidos". A estética da fome faz 
da fraqueza a sua força, transforma em lance de linguagem o que até então é dado técnico. Coloca em suspenso a escala de valores dada, interroga, questiona a realidade do subdesenvolvimento a partir de sua própria prática (Xavier, 2007b, p. 13).

Uma forma específica e exigente, a qual valeria a pena explicar em detalhe. Nada melhor para cumprir esse propósito do que a comparação com filmes mais vinculados às convenções clássicas ou do espetáculo, como são O pagador de promessas (1962), de Anselmo Duarte, e O cangaceiro (1953), de Vitor Lima Barreto, comparados, respectivamente, com Barravento (1961 - 1962) e Deus e o diabo na terra do sol (1963 - 1964). É evidente que não irei aqui acompanhar o raciocínio do crítico passo a passo e nem destrinchar, como ele, as passagens fílmicas do argumento, preocupando-me, principalmente, com a invenção formal de Rocha - capaz de "recolher o conflito de vozes de toda uma época, fazendo a ponte entre o cinema dos anos 1960 e o movimento maior que envolve os caminhos do modernismo posterior à Segunda Guerra Mundial” (Xavier, 2007b, p. 12). Tendo como centro de sua análise o ponto de vista do narrador, ou melhor, o "foco narrativo" (como a história é contada? Como os fatos são dispostos de tal ou tal modo? O que tal movimento de câmera? O que se quer com tal decupagem? etc.), que não pode ser confundido com o autor e deve ser entendido como figura fílmica necessária, Xavier consegue, a um só tempo, capturar a construção formal dos filmes acima citados e lançar mão de um ponto de comparação entre eles.

Já na recepção de Barravento havia uma indicação e uma crítica de que Glauber Rocha estaria preocupado em denunciar o misticismo e a alienação do povo brasileiro, como propunha Luís Carlos Maciel (1965). Para tanto, lançaria mão de uma estrutura dual e simplória que dividiria o mundo entre o Bem (consciência de classe, solidariedade e razão) e o Mal (religião, tradição e irracionalidade), de acordo com Barthélémy Amengual (1991). Uma visão com que o próprio Xavier compactuava, tomando esse filme e Deus e o diabo, como dignos representantes do cinema dos 60, em que havia uma crítica dialética da cultura popular e a ideia de que a religiosidade popular deveria ser entendida sob o signo da alienação. Em contraposição o cinema dos 70 seria baseado em uma política de adesão e positividade absoluta em relação ao popular. 
Contudo, em uma análise mais atenta do filme, pautada por uma postura que privilegia a especificidade de cada película em lugar de uma visão que tenta classificar os filmes de um mesmo diretor sob um único epíteto, Xavier defende que a visão exposta anteriormente era por demais seletiva e incompleta. A montagem, em especial, colocaria essa interpretação em xeque, dado que a utilização particular da câmera e a movimentação das figuras humanas, bem como a coreografia, indicariam outro propósito. Caso os movimentos imanentes da montagem não fossem estudados, não se daria conta, em particular, de um discurso complexo e uma composição digna de um "realismo figural", nos termos de Eric Auerbach (2013) - e que são utilizados por Ismail Xavier -, já que em Glauber Rocha conviveria, como observa Xavier (2007b), tanto o leitor de Marx como um leitor da Bíblia, articulando uma concepção messiânica de revolução, bastante comum na esquerda latino-americana da década de 1960.

À primeira vista, é possível uma análise transcendente e que entenda o filme como uma grande e unívoca denúncia contra a alienação propiciada pela religião. Nessa referência, o processo de trabalho seria entendido como simples exploração e as idas de Firmino e Aruã ${ }^{15}$ para a cidade como algo progressista. Contudo essa visão se embasaria numa leitura superficial da película, a qual não daria conta do significado da sua textura de som e imagem, decisiva para o espectador e foco de tensões. O desbaratamento da visão mais superficial a respeito de Barravento seria apenas possível por meio de uma análise imanente e acurada da perspectiva de narração. Ela deveria tentar verificar se há uma postura de total exterioridade frente aos valores religiosos comunitários ou se, no arranjo fílmico, o narrador assumiria esses valores como matriz orientadora de suas operações.

De posse de uma exposição da dinâmica de Barravento, Xavier demonstra haver uma lei interna de evolução do mundo narrado nada simples e dotada de grandes oscilações, descontinuidades e repetições - muito distinta dos filmes western, ${ }^{16}$ cujo andamento é contínuo e sem contradições pululantes.

\footnotetext{
${ }^{15}$ Firmino e Aruã, representados, respectivamente, pelos atores Antonio Pitanga e Aldo Teixera, são personagens decisivos para a trama de Barravento. Firmino é marcado pela experiência de ida para a cidade, pelo estudo e pela revolta contra o modo de vida dos pescadores e viventes da comunidade. Aruã, por seu turno, é o novo protegido de Iemanjá, tendo seu corpo “fechado”, e, por isso, poderia garantir a segurança da comunidade da costa baiana e assegurar uma boa pesca.

${ }^{16}$ As explicações e reflexões feitas no artigo sobre o western são amparadas nas teorizações do próprio Ismail Xavier.
} 
Haveria, no filme de Rocha, uma complexidade específica, como indicaria a cena em que há uma mudança “repentina” de Aruã para um coqueiro.

A passagem tão ostensiva de Aruã para a árvore, seguida do movimento ascensional da raiz ao topo, estabelece uma relação direta entre seu corpo sexuado, como raiz, e a convulsão da natureza, como resposta à profanação, deflagrada pelo céu nublado e pelo trovão. Desse modo, podemos ver essa cadeia de imagens como uma mediação entre o céu e a terra, se quisermos entre microcosmo (a comunidade e seu solo natal) e macrocosmo (a natureza) (Xavier, 2007b, p. 23). ${ }^{17}$

Cenas como essa forneceriam uma base para se sustentar não uma visão crítica aos equívocos e alienações religiosas e sim o seu contrário: em verdade, o sistema religioso dos pescadores como a melhor explicação dos fatos. Destarte, quando Xavier indicou a hipótese da equivalência dos seis planos de Aruã e o enunciado do corpo sexuado deste estando na raiz do barravento, o crítico atribuiu ao narrador uma adesão aos valores religiosos galvanizadores daquela comunidade, reiterando suas explicações mágicas.

Plano1
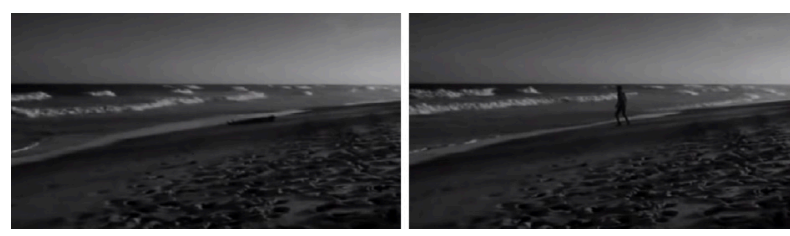

Plano 2

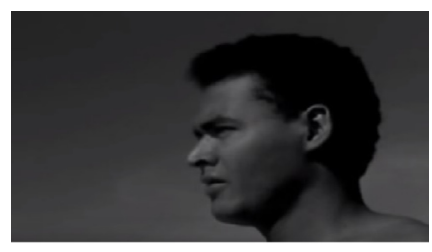

Plano 3

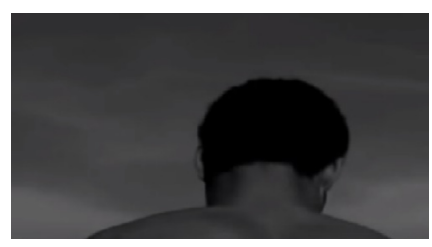

${ }^{17}$ Lembrando que Barravento, segundo o próprio letreiro introdutório do filme, "é o momento de violência, quando as coisas da terra e mar se transformam, quando no amor, na vida e no meio social ocorrem súbitas mudanças” (Xavier, 2007b, p. 23). 
Plano 4
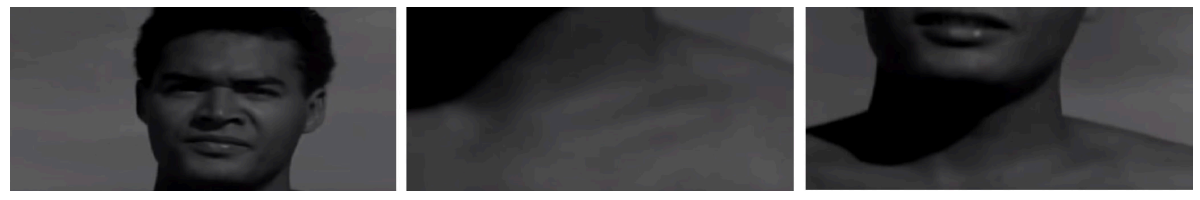

Plano 5
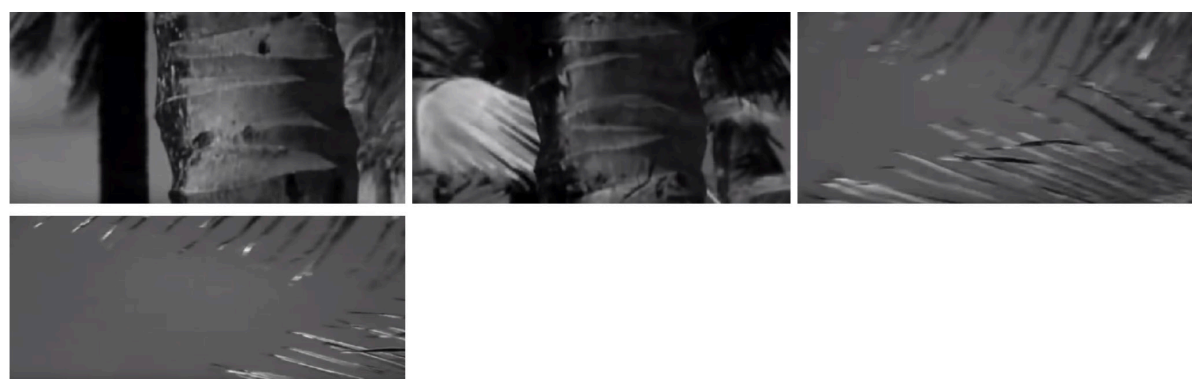

Plano 6

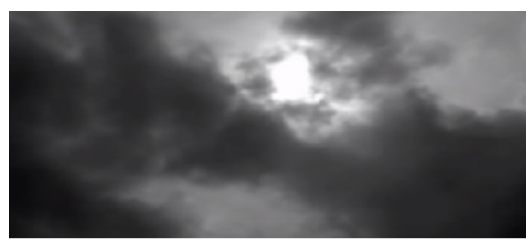

De todo modo, é preciso notar a existência de uma narração oscilante em Barravento. Por conseguinte, seria uma visão extremamente seletiva que defenderia de maneira categórica haver no filme uma crítica externa à religião como alienação. Mesmo assim, haveria uma crítica severa à figura do líder despótico legitimado pela representação religiosa, crítica encarnada em Aruã e Firmino. Quanto à convivência entre miséria e religião, a crítica seria dura, contando com um reclame, presente em dado momento do filme, que seria um possível prenúncio de revolta contra a religião, para, logo depois, a religião voltar com força e se desdobrar em felicidade e ostentação de uma coesão interna ao grupo.

No mesmo diapasão, é necessário que se enxergue a existência de dois regimes temporais distintos dentro da exibição: (i) um tempo que corre em linha reta, expresso, por exemplo, na acumulação dos exploradores, na pregação de Firmino que influencia Aruã e na rede que vem da cidade, e (ii) um tempo circular, da eterna repetição, presente nas regularidades 
rituais, no jogo de compensações e nas reproduções das lendas. Denotarse-ia, assim, um movimento descentrado - presente desde a textura de imagem e som, nas intervenções naturais, até nas ações das personagens - que salienta um percurso não uno em seu foco. Dessa forma, uma análise exterior da comunidade e de sua alienação integra uma organização do mundo social e natural que tem como ponto de partida os valores e representações emanadas da comunidade e sua religião. Uma superposição de perspectivas, a qual impossibilitaria que os focos contraditórios fossem separados e localizados em níveis diferentes do discurso, impedindo, desse modo, uma separação entre o nível mais iluminista do enredo e o mágico-religioso. Em suma,

se, reiteradamente, caracterizei o discurso de Barravento como desequilibrado, convulso, tais desajeitos não são propriedade exclusiva de um modo de montar, sonorizar, movimentar a câmera ou os atores; o enredo é também seu lugar. Em outras palavras, quero evitar a ideia de que existe uma intenção racional que se manifesta no esqueleto da estória, mais consciente e controlável, contraposta à expressão de disposições inconscientes, descontroladas e irracionais, na textura de imagem e som. Quero sublinhar exatamente o oposto: é todo o filme que se contorce para que nele desfile a oscilação entre os valores da identidade cultural - solo tradicional da reconciliação, da permanência e da coesão - e os valores da consciência de classe- solo do conflito, da transformação, da luta política contra a exploração do trabalho. [...] Barravento, filme, é a equação irresolúvel que confronta essas duas perspectivas, recusando o ponto de vista transcendente que, exterior a elas ou privilegiando uma delas, avançaria a resposta una e fecharia o discurso (Xavier, 2007b, p. 51).

Em contraste, em O pagador de promessas, de Anselmo Duarte, a postura é integrativa, equilibrada, com marcações muito claras entre, por exemplo, a consciência do camponês ingênuo e o mundo mercantil, ou a oposição central entre o bar e a igreja. Tudo isso estruturado a partir do ponto de visa de um narrador transcendente, conhecedor de todos os passos do jogo social que se desenrolam em torno da personagem principal (Zé do Burro). A decupagem também é clássica, baseada no modelo hollywoodiano para a filmagem em locação, com a expansão do mundo visível passando a acomodar o filme a tais ideais norte-americanos, assegurando-lhe verossimilhança e 
aproximando-o, em nossa visão, do cinema realista analisado por André Bazin. $^{18}$

Constituição muito distinta é a de Barravento. O filme de Rocha busca uma ruptura com o jogo de perspectivas demarcadas da convenção clássica, tornando mais complexo o trabalho de narração e procurando transpor a distância entre o narrador e o narrado. Procedimento que ganha ares rebeldes e anticolonialistas ${ }^{19}$, expressando uma atitude de resistência aos valores da indústria cultural, pretensamente universais. Postura comum nas vanguardas cinematográficas - desde Eisenstein, passando pelo surrealismo, até o underground estadunidense -, e que ganha certa escala mundial com o cinema novo dos anos 60, a partir de uma narrativa heterogênea e particular, em que a figura de proa é o cineasta franco-suíço Jean-Luc Godard.

Nessa referência é que se pode enxergar semelhanças entre Barravento e um Acossado (1959), de Godard, tendo em vista certa descontinuidade, desequilíbrio de angulações e desenvolvimentos aleatório presentes nos dois filmes. Entretanto, o cineasta brasileiro tinha que se ver com a má formação brasileira, específica e diversa do impulso rebelde do franco-suíço, como argumentou Xavier:

Afinal, no cinema novo, a ideia de experiência assume uma conotação particular, identificando-se com a ideia de realidade brasileira. A contestação do universal abstrato, convenção vigente, traduz-se num projeto cultural anticolonialista porque a particularidade vivida a que se quer dar expressão mais autêntica é a subdesenvolvimento, e o lugar dessa autenticidade é a ideologia da revolução brasileira, por oposição à “mentira” do cinema colonizador (Xavier, 2007b, p. 78).

\footnotetext{
${ }^{18}$ Para melhor esclarecer o nosso comentário sobre Bazin, é possível ver que em um texto como "A evolução da linguagem cinematográfica”, o crítico de cinema divide os diretores entre aqueles que acreditam na imagem e aqueles que acreditam na realidade. Aqueles bem representados por Sergei Eisenstein e estes, pelos diretores do Neorrealismo italiano; aqueles enfatizando a criação de sentido por meio de uma montagem mais visível ao espectador - exemplar disso é o filme O Encouraçado Potemkin, 1925 - e estes enfatizando a profundidade de campo e um plano-sequência, o qual simula a continuidade espaço-temporal, utilizando-se das chamadas montagens invisíveis - tome-se com referência filmes como O ladrão de bicicleta (1948) e $A$ terra treme (1948) (Bazin, 2014, p. 95-113).

${ }^{19}$ Como dizia o próprio Glauber Rocha em seu "Eztetyka da fome 65”: “o cinema novo não pode desenvolver-se efetivamente enquanto permanecer marginal ao processo econômico e cultural do continente latino-americano; além do mais, porque o cinema novo é um fenômeno dos povos colonizados e não uma entidade privilegiada do Brasil: onde houver um cineasta disposto a filmar a verdade e a enfrentar os padrões hipócritas e policialescos da censura, aí haverá um germe do cinema novo. [...] O cinema novo é um projeto que se realiza na política da fome, e sofre, por isto mesmo, todas as fraquezas consequentes de sua existência” (Rocha, 2004, p. 67).
} 
Com Deus e o diabo na terra do sol (1963-1964), a postura é parecida, mas mais madura e desenvolta. O filme é organizado em torno da vida do casal de camponeses Rosa e Manuel, explicitando sua condição social e de trabalho, seus embates com os donos do poder e a vinculação de ambos à rebeldia messiânica e à violência do cangaço. A narrativa é perpassada por três momentos essenciais de ruptura e mergulho no messianismo e no cangaço - nada homogêneos, contínuos e lineares. Ao contrário, enfatiza-se a montagem, algo que Ismail Xaver aproxima ao estilo fílmico de Eisenstein $(2002)^{20}$ - na qual se salienta a descontinuidade e o sentido subjacente ao que é montado. Nesse filme, recorre-se até mesmo a procedimentos retóricos, como no final, em que o espaço-tempo da ação é dissolvido em prol de uma construção metafórica: a presença do mar, oposta ao sertão. Na modulação descontínua abre-se espaço para comentários explícitos sobre o próprio imaginário desenvolvido, bloqueando certos gestos de modo a sublinhar sua significação social, o que faz com que Xavier aproxime o estilo glauberiano do anti-ilusionismo de Brecht. ${ }^{21}$

Evidencia-se durante o filme a presença de uma grande diversidade de registros na relação narrador/ narrado, com diferentes tipos de intervenção das figuras de mediação, múltipla "em suas vozes, pelo som e pela imagem”, que "ora permanece colada à experiência dos protagonistas, ora a observa de um ponto de vista mais distante, organizando-a pela montagem e fornecendo o comentário retrospectivo ou antecipador do cantador” (Xavier, 2007b, p. 103). Como no contraste de Manoel, que em sua fase beata é "exposto" via

\footnotetext{
${ }^{20}$ Para esclarecer a comparação, é preciso lembrar que, em Eisenstein, a montagem não deve ser tomada como uma ligação tranquila de dois elementos. Ao contrário, para o soviético, ela deve ser tomada como colisão e conflito, de sorte que, do choque de dois fatores determinados, nasceria um novo conceito. Trocando em miúdos: "se a montagem deve ser comparada a alguma coisa, então uma legião de trechos de montagem, de planos, deveria ser comparada à série de explosões de um motor de combustão interna, que permite o funcionamento do automóvel ou trator: porque, de modo semelhante, a dinâmica da montagem serve como impulsos que permitem o funcionamento de todo o filme” (Eisenstein, 2002, p. 43).

${ }^{21}$ Nesse momento, é interessante ter em mente que Brecht e Eisenstein aparecerem nas análises de Xavier sobre o cinema de Glauber Rocha não de forma gratuita. Dessa forma, com Jameson, podemos notar certa aproximação entre Brecht e Eisenstein em seus feitos críticos: “mas parece aconselhável 'estranhar' ou desfamiliarizar o chamado efeito de estranhamento a fim de expressar algo de sua função original e histórica e também de surpreender a variedade de formas que ele é capaz de assumir. Brecht apresentou-nos muitas 'definições' desse termo, que parece ter migrado do 'ostranenie' ou 'estranhamento' dos formalistas russos a partir das inúmeras visitas de soviéticos modernistas como Eisenstein ou Tretiákov a Berlim. Como o conceito de 'montagem' de Eisenstein, o efeito-V permitiu a Brecht organizar e coordenar um grande número de traços de sua prática teatral e estética” (Jameson, 2013, p. 63-64). De acordo com Xavier, esse estranhamento desalienador conseguido por meio da montagem seria uma constante nos filmes de Glauber Rocha.
} 
montagem permeada por tensões e em sua fase cangaceiro é mostrado mais em planos-sequência de maior duração. Assim, é na convergência entre câmera e cordel, do erudito e do popular, que se leva ao limite a convivência de perspectivas, de um modo dialógico.

No plano mais geral da película, há a coexistência de dois movimentos em seu interior: o questionamento da metafísica em nome da liberação do homem - sujeito da história, télos presente de vários modos no filme - e outro, que se sobrepõe ao primeiro e se caracteriza pela sistemática e gradativa afirmação de uma ordenação que comanda o destino dos sujeitos e confere sentido às suas ações, de sorte que o foco nas determinações passa a ser transcendente. O desenvolvimento é significativamente pautado em uma interdependência fundamental: quem fecha o movimento de libertação e afirma o humanismo do homem desalienado é, justamente, o agente da chamada ordem maior (o destino), figura da alienação desse mesmo humanismo expresso durante o filme. Destarte, o resultado dessa interdependência é um percurso libertador forjado não pelo homem, mas sim pelo agente da ordem maior, o destino que, quiçá, trabalha em direção à conclusão de que o homem é o sujeito histórico por excelência.

Nesses termos, o filme configura um processo social que "de fato, caminha como realização de um destino, enquanto que, de direito, o recado explícito das vozes outorga à humanidade a condição de sujeito" (Xavier, 2007b, p. 141). A transformação - ou a consumação do télos - aparece nele como um pressuposto, pela práxis ou pelo destino; a história, por seu turno, transparece em toda a película e está devidamente assentada no terreno da teleologia. À vista de tudo o que foi exposto, é lícito dizer que o filme em questão seria caracterizado pela interação sistemática de enunciados, tornando ambíguo o princípio que move os processos; na estrutura, por seu lado, o ponto decisivo é a lacuna do presente, conformada como uma estratégia da retórica da ambivalência; e, por último, na teleologia da película, a expressão do desejo está acima das explicações da ciência social, de sorte que a esperança reaparece sistematicamente como antecipação da consumação de um télos. Representando um amplo movimento da consciência rebelde, Deus e o diabo tira a sua força não da historicidade do particular e sim de uma história baseada na transfiguração do presente em um ponto sem representação, o qual tem como direção certo rumo a um fim dado. 
Tais proposições são essencialmente distintas do chamado western, gênero que, de acordo com o próprio Xavier (2007b), se apropriou do imaginário gestado na experiência histórica das regiões fronteiriças do século 19 nos Estados Unidos da América, com o intuito de criar uma espécie de epopeia do processo civilizador. Tal perspectiva norte-americana tem o efeito de transfigurar ideologicamente a barbárie do processo de acumulação capitalista na América. Ademais, o gênero promove uma ressurreição do assim considerado mundo arcaico, exatamente o outro de nossa época e sociedade, mas que heroicamente teria preparado o terreno para a civilização moderna triunfante, baseada no equilíbrio e no bem-estar. Como não poderia deixar de ser, a figuração desse processo se dá a partir da disputa de vilões e heróis bem marcados.

O cangaceiro de Vitor Lima Barreto, que se vale dos preceitos do western, evidencia a inadequação entre uma forma hollywoodiana importada para um contexto diverso. Daí resulta o desencontro de uma série de elementos, como a presença do índio caraíba, a fala caipira dos personagens e o tom declamatório dos diálogos. Já em Deus e o diabo de Glauber Rocha o sertão é um mundo localizado fora da história, depositário de uma rusticidade bárbara que cabe ao progresso, vindo de fora, exterminar. No filme de Barreto o cangaceiro é um dado, cujo comportamento peculiar é espetacularizado, principalmente pelo narrador civilizado. Na película de Rocha, por sua vez, a experiência camponesa diz respeito ao processo histórico, sendo a violência identificada como o momento de práxis do cangaceiro com a própria revolta. Do ponto de vista composicional, a distinção também não poderia ser maior, visto que $O$ cangaceiro tenta a todo momento garantir a unidade, com ritmos muito bem organizados, além de uma música que é funcional a seus temas, de forma que cada cena se torna eloquente e acabada. O filme de Glauber Rocha, no que lhe concerne, destaca a descontinuidade a partir de uma alegoria cujo movimento afirma avanços, os quais, por seu turno, não encontram pontos seguros de apoio.

Segundo Xavier, a produção de Glauber Rocha deve ser compreendida também tendo em vista o momento político e histórico que se vivia no país durante o populismo. Em termos culturais, o Brasil seria marcado por uma hegemonia da esquerda, mantida até em meio a ditadura de direita no Brasil. No entanto, a esquerda privilegiava o anti-imperialismo diante da luta de classes (Schwarz, 2008). Não por acaso, o nacional-popular estava na ordem do dia, tendo sua maior cristalização nos Centros Populares de Cultura (CPCs). 
Levando em conta esse chão histórico, é possível afirmar que os filmes de Glauber Rocha ultrapassariam essas representações. O diretor recusa, em especial, a postura didático-instrumental dos CPCs, produzindo uma incorporação extremamente interessante das representações populares nas suas obras. Seguindo Xavier,

Barravento e Deus e o diabo estão, inegavelmente, inseridos nesse contexto de problemas, impasses, paradoxos. Porém, dentro dele, sua condição é peculiar. Marcados pela postura de conscientização própria aos projetos da época, os dois filmes manifestam algo além do autoritarismo populista, pois a boa arte não se reduz a um mero duplo da ideologia. Longe de, simplesmente, refleti-la e mascarála, evidenciam as suas contradições porque internalizam o duplo movimento de valorização-desvalorização do popular. Seguindo a tendência geral, elaboram a crítica das representações das classes dominadas na base do conceito de alienação. Mas, contendo em si um movimento de afirmação dessas representações como resistência, lugar de uma identidade a ser tomada como ponto de partida, esses filmes se marcam também pela adesão e elogio. Assumem, para valer, as significações por elas elaboradas e buscam nelas alguma lição sobre a experiência, não apenas a forma comunicativa (Xavier, 2007b, 191-192).

A teleologia apresentada nos dois filmes pressupõe um plano histórico já desenhado, trazendo em si as premissas que baseavam as propostas políticas de boa parte da esquerda, nas quais o cumprimento de determinadas etapas levaria à redenção histórica. De forma irônica, os filmes conseguem revelar que a história, na cabeça dos "não-alienados", era pensada de uma maneira muito afinada com a noção de destino dos "alienados"; a lógica profética orienta ambas, como em Deus e o diabo, no qual a ponte entre o passado e o futuro é tentada a partir de uma noção de "revolução como retomada da experiência rebelde presente na memória que reelabora as tradições do sertão" (Xavier, 2007b, p. 192).

No plano formal, a inovação de Glauber Rocha também é um achado, pois sua estética da violência formula uma crítica profunda às fórmulas usadas pelo espetáculo artístico convencional, supostamente universalista, que apenas leva à realização da lógica mercantil. Achados que, por sua complexidade e textura, são de alcance mais amplo e foram fundamentais ao quadro do movimento internacional do(s) cinema(s) novo(s). Nesse bojo, Terra em transe, apesar de ser uma resposta à crise do projeto pós-64, em 
que realiza uma crítica mordaz à esquerda e seus sistemáticos equívocos, coloca em movimento o principal impulso glauberiano de totalização. Nele, traça-se um esquema do mundo sempre com múltiplas determinações que condenam uma visão fragmentada da experiência. Do mesmo modo, como em Deus e o diabo na terra do sol, os movimentos cruzados reaparecem, colocando simultaneamente os interesses de classe e os parâmetros do ritual e da magia, chegando à metáfora da terra em transe em relação ao golpe político, o que indicaria que a lógica da superstição ainda é a melhor para se pensar o comportamento da esquerda e das classes dominantes, e completando um movimento assim formalizado por Xavier:

marcado por um impulso de contradição, Glauber teceu em suas imagens um drama barroco que, no sentido proposto por Walter Benjamin, só se explicitou com maior clareza na estrutura e no estilo de Terra em transe [1967]. Este filme trazia uma reflexão exasperada diante do que o cineasta entendia como um reiterado adiamento bem próprio à história truncada de uma nação a construir, uma naçãoproblema, talvez uma miragem, de qualquer modo um hipotético ponto futuro que em Deus e o diabo [1963-64], havia pensado numa tonalidade distinta. Na cena que configurou no sertão, a questão central não era a crise de um projeto, mas a forma peculiar de Glauber compor uma teleologia - a da formação nacional - que tem seu parentesco com outros exemplos de narrativas de fundação, mas exibe nítida diferença. $O$ seu ponto essencial é o reconhecimento de que tal formação não se completou, é da ordem da profecia (Xavier, 2007b, p. 10-11).

Nos filmes glauberianos, a procura da justiça é recolocada a cada passo, não dando ensejo à celebração da totalidade, visto que incompleta. No lugar de celebrar, há, na verdade, reflexão tensa sobre a violência e o passado e que se volta para uma história baseada na ambivalência. Tendo essas premissas em vista, é possível entender a inovação formal de Glauber, que traz para o primeiro plano a descontinuidade, com uma alegoria que enseja movimentos de avanço, mas que não contam com os pontos seguros de apoio de um western. Desta feita, Rocha pode incorporar formalmente os dados da realidade que passam a ser mola estruturante e propulsora de suas películas e, com isso, forjar tanto uma crítica das convenções fílmicas tradicionais e do centro do capitalismo, quanto uma crítica aos próprios pressupostos 
do capitalismo, visto que a fome, enquanto tema e forma, era criticamente jogada nas telas não como dado culturalmente local, mas como necessidade interna ao processo ampliado de reprodução geral do capital.

\section{Considerações finais}

É possível, à vista do que foi por nós exposto até aqui, notar que Ismail Xavier, por meio de uma análise imanente dos filmes de Glauber Rocha e do cotejo destes com produções audiovisuais mais tradicionais, pode ver a formação de uma forma artística específica a qual internalizava a má formação brasileira e a transformava em princípio estruturante do cinema glauberiano. Dessa forma, mostramos que a experiência intelectual e os feitos críticos de Xavier também são devedores de nossa matriz periférica e das discussões que conformaram o quase gênero da formação, o que o aproxima de outros críticos de arte, como Rodrigo Naves e Roberto Schwarz.

Como bem nota Saraiva (2019), tais reflexões do crítico de cinema foram decisivas para a consolidação do campo de estudos cinematográficos brasileiro, tanto pela profundidade da interpretação alcançada, quanto pela riqueza do instrumental analítico desenvolvido. Desta feita, tornamse questionáveis argumentações de que as discussões sobre formação e seu legado deveriam ser superadas, visto que, como argumentam, com a globalização e o fim do desenvolvimentismo, o Brasil deveria se integrar às redes globais e às cadeias produtivas globais das ideias. Até porque, caso isso fosse efetivado, como aponta Roberto Schwarz (2021a) a partir do conto "O punhal de Martinha", de Machado de Assis, deixaríamos de lado Martinha (a referência nacional) e abriríamos terreno apenas para Lucrécia (encarnação do elemento cosmopolita), o que, no final das contas, nos legaria uma posição política e intelectual baseada num cosmopolitismo abstrato e numa crítica indefinida. Posição diversa, por exemplo, da de mestres da periferia capitalista, a saber, Machado de Assis e Jorge Luís Borges, os quais, de formas distintas, lograram, a partir da elaboração de experiências periféricas, fazer uma crítica aos pressupostos pretensamente universais dos países centrais do capitalismo e forjar diagnósticos cortantes a respeito da modernidade. Algo também feito, via cinema, por Glauber Rocha, cuja forma artística foi desvendada por Ismail Xavier e sua crítica calcada na análise pormenorizada das formas e de suas implicações sociais e políticas. 


\section{Referências}

Adorno, Theodor W. (1970). Teoria estética. Edições 70.

Alcides, Sérgio. (2011) O momentâneo da "Formação". O Eixo e a Roda, 20(1), 141-154. http://dx.doi.org/10.17851/2358-9787.20.1.141-154

Amengual, Barthélémy. (1991). Glauber Rocha e os caminhos da liberdade. In P. E. S. Gomes et al. (Orgs.), Glauber Rocha (pp. 95-122). Paz e Terra.

Arantes, Paulo E. (1991) Ideologia francesa, opinião brasileira. Novos Estudos, 3(28), 141-161.

Arantes, Paulo E. (1996). O fio da meada. Editora Paz e Terra.

Arantes, Paulo E. (1994). Um departamento francês de ultramar. Editora Paz e Terra.

Arantes, Otília, \& Arantes, Paulo E. (1997a). Sentido da formação. Editora Paz e Terra.

Arantes, Otília, \& Arantes, Paulo. (1997b). O sentido da formação hoje. Praga, (4), 95-109.

Arruda, Maria A. N. (2017). El concepto de formación en tiempos críticos: esbozo de reflexión. Sociológica, 1(90), 47-68.

Arruda, Maria A. N., \& VILLARINO, Vizin L. (2016). O conceito de formação em tempos críticos: esboços de reflexão [Apresentação de artigo]. $40^{\circ}$ Encontro anual da ANPOCS, Caxambu-MG.

Auerbach, Erich. (2013) Mimesis. Perspectiva.

Baptista, Abel B. (2005). O cânone como formação: a teoria literatura brasileira de Antonio Candido. In A. B. Baptista, O livro agreste: ensaio de curso de literatura brasileira (pp. 41-80). Editora Unicamp.

Bazin, André. (2014). O que é cinema? Cosac Naify.

Bernardet, Jean-Claude, \& Reis, Francis V. (2018). O autor no cinema. Edições SESC.

Candido, Antonio. (2013). Formação da literatura brasileira. Rio de Janeiro.

Candido, Antonio. (2011). A educação pela noite. Ouro sobre Azul.

Candido, Antonio. (1986). Informe político. In C. A. Calil, \& M. T. Machado (Org.), Paulo Emilio (pp. 55-72). Embrafilme; Brasiliense.

Cara, Salete. (2014). Formação e negatividade. In L. A. Alves (Org.), A formação em perspectiva: ensaios de literatura, cultural e sociedade (pp. 323-339). Beco do Azougue. 
Cardoso, Fernando H. (1972). Empresário industrial e desenvolvimento econômico. Difel.

Cardoso, Fernando H. (1971). Política e desenvolvimento em sociedades dependentes: ideologias do empresariado industrial Argentino e Brasileiro. Zahar Editores.

Cardoso, Fernando H. (1967). Hegemonia Burguesa e Independência Econômica. Revista Civilização Brasileira, v.17, n.1, p. 67-95.

Cardoso, Fernando H., \& Faletto, Enzo. (2011). Desenvolvimento e dependência na América Latina: ensaio de interpretação sociológica. Civilização Brasileira.

Cevasco, Maria E. (2014). Ainda a formação. In L. A. Alves, Luis Alberto (Org.), A formação em perspectiva: ensaios de literatura, cultural e sociedade (p. 275-303). Beco do Azougue.

Chibber, Vivek. (2013) Post-colonial theory and the spectre of capital. Verso.

Corrêa, Zé Celso M. (1998). O poder de subversão da forma. In Z. C. M. Corrêa, Primeiro ato (pp. 95-117). Editora 34.

Eisenstein, Sergei. (2002). A forma do filme. Zahar.

Estrada, Henrique R. (2015). O conceito de formação na historiografia brasileira. In B. F. Medeiros et al. (Org.), Teoria e historiografia: debates contemporâneos (pp. 253-277). Paco Editorial.

Faoro, Raymundo. (2012). Os donos do poder: formação do patronato político brasileiro. Globo.

Furtado, Celso. (1995). Formação econômica do Brasil. Companhia Editoria Nacional.

Gomes, Paulo E. S. (2001). Cinema: trajetória do subdesenvolvimento. Paz e Terra.

Gomes, Paulo E. S. (1986). Declaração; Comentário; Plataforma da nova geração; Manifesto da União Democrática Socialista (UDS). In C. A. Calil \& M. T. Machado (Org.), Paulo Emílio (pp. 72-96). Brasiliense; Rio de Janeiro: Embrafilme.

Hegel, Georg W. F. (2012). Fenomenologia do espírito (8. ed.). Vozes.

Jameson, Fredric. (2013). Brecht e a questão do método. Cosac Naify.

Lage, Victor C. (2016). Interpretations of Brazil, Contemporany (De) Formations. [Tese de Doutorado, Pontifícia Universidade Católica do Rio de Janeiro]. https://doi.org/10.17771/PUCRio.acad.27613 
Le Corbusier. (2004). Precisões: sobre um estado presente da arquitetura e do urbanismo. Cosac Naify.

Lebrun, Gerard. (1988). O avesso da dialética. Companhia das Letras.

Machado de Assis, José M. (2015). Notícia da atual literatura brasileira: instinto de nacionalidade. In J. M. M. Assis, Machado de Assis: obra completa em quatro volumes (Vol. III, pp. 1177-1184). Editora Nova Aguilar.

Maciel, Luiz C. (1965). Dialética da violência. In G. Rocha, Deus e o diabo na terra do sol (pp. 200-219). Paz e Terra.

Marino, Rafael. (2017). Artes plásticas sob o crivo da formação: a discussão sobre forma e processo social em Gilda de Mello e Souza e Rodrigo Naves. Plural, 24(2), 207-228. https://doi.org/10.11606/issn.21768099.pcso.2017.143003

Mello e Souza, Gilda de. (2008). Exercícios de leitura. Editora 34.

Mendes, Adilson. (2019). O cinema brasileiro moderno por Ismail Xavier. As formas do transe: a análise fílmica de Ismail Xavier como sismógrafo histórico. In F. Lunardelli et al. (Ed.), Ismail Xavier: um pensador do cinema brasileiro (pp. 130-145). Edições SESC.

Naves, Rodrigo. (2011). A forma difícil: ensaios sobre arte brasileira. Companhia das Letras.

Nobre, Marcos. (2015). Da “formação” às “redes”: Filosofia e cultura depois da modernização. In R. F. Pinto, D. Spencer \& T. Telles (Org.), Teoria crítica e Adorno: ideias em constelação (pp. 45-73). Valer Editora.

Nobre, Marcos. (2012). Da “formação” às "redes”: Filosofia e cultura depois da modernização. Cadernos de Filosofia Alemã, 1(19), 13-36. https:// doi.org/10.11606/issn.2318-9800.v0i19p13-36

Pedrosa, Mário. (2004). Acadêmicos e modernos: textos escolhidos III. Edusp.

Prado Jr., Caio. (2011). Formação do Brasil contemporâneo. Companhia das Letras.

Ricupero, Bernardo. (2011). Sete lições sobre as interpretações do Brasil. Alameda.

Ricupero, Bernardo. (2010). Formação da literatura brasileira nos anos 1950. Revista Água Viva, 1(1), 1-5. https://doi.org/10.26512/aguaviva.v1i1.10534

Ricupero, Bernardo. (2008). Da formação à forma: ainda "as ideias fora do lugar”. Lua Nova, 1(73), 59-69. https://doi.org/10.1590/S0102$\underline{64452008000100003}$

Rocha, Glauber. (2003). Revisão crítica do cinema brasileiro. Cosac Naify. 
Rocha, Glauber. (2004). Revolução do Cinema Novo. Cosac Naify.

Santiago, Silviano. (2014, 7 set.). Anatomia da formação: a literatura brasileira à luz do pós-colonialismo. Folha de São Paulo. https://m. folha.uol.com.br/ilustrissima/2014/09/1511606-a-literatura-brasileiraa-luz-do-pos-colonialismo.shtml

Saraiva, Leandro R. (2019). As formas do transe: a análise fílmica de Ismail Xavier como sismógrafo histórico. In F. Lunardelli et al. (Org.), Ismail Xavier: um pensador do cinema brasileiro (pp. 145-160). Edições SESC.

Schwarz, Roberto. (2014). Sequências brasileiras: ensaios (2. ed.). Companhia das Letras.

Schwarz, Roberto. (2012a). Martinha versus Lucrécia. Companhia das Letras.

Schwarz, Roberto. (2012b). Um mestre na periferia do capitalismo: Machado de Assis. Duas Cidades; Editora 34.

Schwarz, Roberto. (2008). O pai de família e outros estudos. Companhia das Letras.

Wisnik, José M. (2008). Veneno remédio. Companhia das Letras.

Xavier, Alberto (Org.). (2003). Depoimento de uma geração: arquitetura moderna brasileira. Cosac Naify.

Xavier, Ismail. (2013). Entrevista com Ismail Xavier. Estudos históricos, 1(51), 213-238.

Xavier, Ismail. (2012). Alegorias do subdesenvolvimento: cinema novo, tropicalismo, cinema marginal. Cosac Naify.

Xavier, Ismail. (2007a). O mundo tem as caras que pode ter. In M. E. Cevasco \& M. Ohata (Org.), Um crítico na periferia do capitalismo (pp. 212226). Companhia das Letras.

Xavier, Ismail. (2007b). Sertão Mar: Glauber Rocha e a estética da fome. Cosac Naify.

\section{(cc) $\mathrm{EY}$}

Licenciado sob uma Licença Creative Commons Attribution 4.0 